Alicja Matczuk (Lublin)

\title{
Rękopiśmienna Bibliografia prawa polskiego od najdawniejszych czasów do roku 1823 Jana Wincentego Bandtkie-Stężyńskiego w zbiorach Biblioteki Jagiellońskiej
}

Pierwsze próby rejestracji piśmiennictwa prawniczego podejmowane były w Polsce już w XVIII w. Wykazy zawierające literaturę prawniczą występowały w obrębie bibliografii historycznych Samuela Hoppiusa, Dawida Brauna oraz Józefa Andrzeja Załuskiego ${ }^{1}$. Polska bibliografia prawnicza potraktowana odrębnie pojawiła się w XIX w. Już na początku tego stulecia prawnicy Królestwa Polskiego zwracali uwagę na brak spisów literatury prawniczej, która była tak mocno rozbudowana, że usystematyzowanie i wykazanie jej w bibliografiach stało się pilną koniecznością ${ }^{2}$. Początkowo redagowali oni tylko działy prawne zamieszczane w czasopismach prawniczych i bibliografiach o charakterze ogólnym. Jedną z wcześniejszych prób stworzenia bieżącej bibliografii prawniczej były zestawienia nowych książek ogłaszane w dziale „Literatura” w „Themis Polska” (1828-1830) pierwszym w Polsce periodyku naukowym z zakresu prawa ${ }^{3}$.

Uczonym, który jako pierwszy podjął się trudu opracowania całości polskiego piśmiennictwa prawniczego, był Jan Wincenty Bandtkie-Stężyński, historyk prawa. Niestety, jego obszerna retrospektywna bibliografia, doprowadzona do 1823 r., nie

${ }^{1}$ S. Hoppius, De scriptoribus historiae Polonicae schediasma literarium..., Dantisci 1707; D. Braun, De scriptorum Poloniae et Prussiae historicotum et [juris]... Coloniae [w rzeczywistości Elbląg] 1723; J.A. Załuski, Biblioteka historyków, prawników, polityków..., wyd. J. Muczkowski, Kraków 1823.

${ }^{2}$ B. Koredczuk, Udziat inteligencji prawniczej Królestwa Polskiego w kształtowaniu kultury ksiażki (1815-1915), Wrocław 2011, s. 260.

${ }^{3} \mathrm{O}$ historii „Themis Polska” zob. S. Milewski, A. Radzik, Themis i Pheme. Czasopiśmiennictwo prawnicze w Polsce do 1939 roku, Warszawa 2011, s. 46-62. 
doczekała się prasy drukarskiej. Losy tego rękopisu i jego zawartość nie zostały dotąd gruntownie zbadane, nie licząc drobnych wzmianek pojawiających się na marginesie omawiania sylwetki i zainteresowań naukowych uczonego ${ }^{4}$. Podstawowym źródłem, z którego czerpią informacje badacze piszący o tym dziele, jest biogram Bandtkiego pióra Janiny Ender, zamieszczony w 1972 r. w Stowniku pracowników ksiązki polskiej. Odnotowano w nim: „W zbiorach Biblioteki Jagiellońskiej znajdują się nieopublikowane prace: Bibliografia prawa polskiego od najdawniejszych czasów do roku 1823 napisana przez... (rkp 4917) oraz Historia bibliografii prawa polskiego napisana przed rokiem 1830 przez... (rps. 5760) z częścią wydruku próbnego obejmującego 180 stron"s. Z kolei w tomie czwartym Bibliografii literatury polskiej „Nowy Korbut” (1966 r.), w wykazie prac J.W. Bandtkiego pod numerem 14 znajdujemy następujący zapis bibliograficzny: Bibliografia prawa polskiego od najdawniejszych czasów do roku 1823. Kr. 1825. I dalej w adnotacji: „Rękopis 5760 zawiera tę samą bibliografię [co rkp. 4917 - przyp. autora] przygotowaną do druku, częściowo w korektach pt. Historia bibliografii prawa polskiego napisana przed $r .1830$ przez..." . Fakt istnienia tych rękopisów odnotowuje również Inwentarz rękopisów Biblioteki Jagiellońskiej, sporządzony pod koniec XIX w. przez Władysława Wisłockiego. Przypuszczalnie to ten inwentarz, a nie same rękopisy, stanowił źródło informacji dla autorów wspomnianych wcześniej publikacji. Niestety, informacje te zostały przez nich zniekształcone i są przekłamane. Otóż opis inwentarzowy rękopisu Historii bibliografii prawa (rkp. 5760) odnotowuje, że ów rękopis ma akceptację cenzury warszawskiej oraz zawiera ,autograf J.W. Bandtkiego str. druk 115-294 na czele, wyjęte z literatury Bentkowskiego i gęsto dopiskami zasiane" ". Jak można zauważyć, nie ma w opisie wzmianki o wydruku próbnym, za to jest mowa o rozdziale z bibliografii Bentkowskiego, zawierającym liczne uzupełnienia, oraz o manuskrypcie Bandtkiego.

Wszystko wskazuje na to, że w trakcie przygotowania bibliografii do druku powstały dwa rękopisy o odmiennych tytułach. Stanowią one ciekawe świadectwo losów dzieła Bandtkiego. Nie wiadomo jednak, jaka była chronologia ich powstania. Z przytoczonych wyżej opracowań wynikałoby, że rękopis pierwotnie nosił tytuł Bibliografia prawa polskiego, jednak do publikacji został skierowany pod nazwą Historia bibliografii prawa. Gdyby tak było w istocie, to dlaczego dzieło to jest bardziej znane w literaturze przedmiotu pod pierwszym tytułem? Nie wiadomo

${ }^{4}$ B. Koredczuk, Zainteresowania bibliograficzne i bibliofilskie profesora historii prawa Jana Wincentego Bandtkie-Stężyńskiego (1783-1846), „Acta Universitatis Wratislaviensis. Bibliotekoznawstwo" 2008, nr 27, s. 51-54; eadem, Udziat inteligencji prawniczej..., s. 261-262.

${ }^{5}$ J. Ender, Bandtkie-Stężyński Jan Wincenty [w:] Słownik pracowników książki polskiej, Warszawa-Lódź 1972 s. 30; B. Koredczuk, Udziat inteligencji prawniczej..., s. 261.

${ }^{6}$ Bandtkie-Stężyński Jan Wincenty [w:] Bibliografia literatury polskiej „,Nowy Korbut”, t. 4, Warszawa 1966, s. 221.

${ }^{7}$ Inwentarz rękopisów Biblioteki Jagiellońskiej, oprac. W. Wisłocki, Kraków 1939, s. 488. 
również, kiedy i dlaczego tytuł uległ zmianie, czy pochodził on od J.W. Bandtkiego, czy może sformułował go ktoś inny. Wreszcie, co było powodem, że bibliografia nie została opublikowana i czy faktycznie jej druk został zawieszony, o czym ma świadczyć domniemany wydruk próbny?

Opierając się na szczątkowych w istocie danych, a często przypuszczeniach powstałych z wielu fragmentarycznych informacji oraz na wnikliwej analizie rękopisów, podjęto próbę udzielenia odpowiedzi na powyższe pytania. Artykuł ma na celu, oprócz ukazania genezy i losów bibliografii Bandtkiego, przedstawienie jej zawartości i metody opracowania. Dlatego starano się ukazać świadomość bibliograficzną tego uczonego przez naświetlenie problemów dotyczących metody opracowania bibliografii, a więc zakresu, zasięgu, zasad opisu i porządkowania materiału bibliograficznego, zwrócając uwagę na występujące w nich elementy nowatorskie.

W szczegóły życiorysu Jana Wincentego Bandtkiego nie zagłębiano się, ponieważ literatura na ten temat jest dość bogata ${ }^{8}$. Zasygnalizowano tylko ważniejsze fakty z życia tego uczonego, niezbędne do wyjaśniania niektórych kwestii związanych z omawianą problematyką.

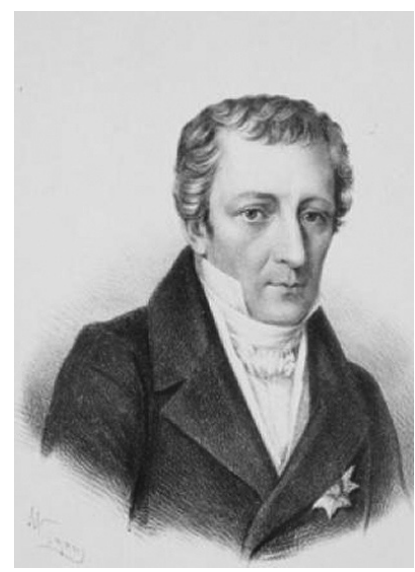

Fot. 1. Jan Wincenty Bandtkie-Stężyński (1783-1846)

Źródło: http://www.polacyzwyboru.pl/bohaterowie/biogramy/jan-wincenty-bandtkie

J.W. Bandtkie urodził się w 1783 r. w Lublinie. Po ukończeniu tam prywatnej szkoły niemiecko-polskiej dalsze nauki - podobnie jak jego starszy brat, Jerzy Samuel - pobierał w gimnazjum św. Elżbiety w Wrocławiu. Następnie, w latach

8 Zob. m.in. S. Kutrzeba, Bandtkie Jan Wincenty [w:] Polski Stownik Biograficzny, t. 1, Kraków 1925, s. 259-260; J. Ender, Bandtkie-Stężyński..., s. 30-31; B. Koredczuk, Zainteresowania bibliograficzne..., s. 48-51; K. Pol, Poczet prawników polskich, Warszawa 2000, s. 63-73. 
1803-1806, studiował prawo na uniwersytecie w Halle. Przez dwa lata był tam nauczycielem języka polskiego, z polecenia Feliksa Bentkowskiego, który zaproponował go na swojego następcę. Od tego czasu obaj uczeni pozostawali w wielkiej przyjaźni.

Mimo propozycji intratnych posad w Niemczech w 1806 r. Bandtkie wrócił do kraju. W następnym roku został asesorem przy sądzie apelacyjnym w Warszawie, a w 1808 r. notariuszem departamentu warszawskiego. Rok później został mianowany notariuszem na całe Księstwo Warszawskie. Po utworzeniu Królestwa Polskiego został potwierdzony na tym urzędzie przy sądzie apelacyjnym i piastował to stanowisko aż do $1843 \mathrm{r}$. W $1844 \mathrm{r}$. mianowano go radcą stanu i członkiem Komisji Rządowej Sprawiedliwości.

Oprócz zajmowania się pracą zawodową Bandtkie rozwijał działalność naukową i pedagogiczną. W $1808 \mathrm{r}$. został profesorem i pierwszym naczelnikiem nowo założonej Szkoły Prawa, która była zalążkiem późniejszego Wydziału Prawa na utworzonym w 1816 r. Uniwersytecie Warszawskim. Bandtkie walnie przyczynił się do powstania Uniwersytetu, za co otrzymał w $1819 \mathrm{r}$. szlachectwo dziedziczne z przydomkiem Stężyński. Do 1831 r., czyli przez cały okres istnienia tej uczelni, pełnił w niej funkcję dziekana Wydziału Prawa. W szkole, a potem na uniwersytecie wykładał prawo rzymskie i historię prawa polskiego. Należał do wielu towarzystw naukowych: był członkiem Warszawskiego Towarzystwa Przyjaciół Nauk, członkiem korespondentem Krakowskiego Towarzystwa Naukowego i członkiem honorowym Uniwersytetu Wileńskiego. W 1814 r. Uniwersytet w Królewcu przyznał mu tytuł doktora praw. Bandtkie zmarł 7 lutego 1846 r. w Warszawie.

To, że zainteresował się bibliografią, zawdzięczał swemu starszemu bratu, Jerzemu Samuelowi Bandtkiemu, który był profesorem i pierwszym uniwersyteckim wykładowcą bibliografii na Uniwersytecie Jagiellońskim oraz kierownikiem Biblioteki Jagiellońskiej. W przeciwieństwie do brata jednak Jan Wincenty nie interesował się teorią i historią bibliografii, lecz traktował bibliografię jako ważny środek do zachowania dorobku umysłowego ludzkości, przy czym jej przydatność oceniał jedynie od strony praktycznej, jako pomocy w pisaniu prac naukowych ${ }^{9}$. Głównym przedmiotem jego zainteresowań bibliograficznych były dzieje prawa polskiego.

Pierwsze próby Bandtkiego w dziedzinie bibliografii prawniczej odnajdujemy w jego pracy napisanej po łacinie pt. De studio iuris polonici (Vratislaviae 1806). I chociaż pisał on o źródłach prawa polskiego, na końcu tej dysertacji zamieścił spis polskiej literatury prawniczej zatytułowany „De subsidiis ad studium juris Polonici necessatiis", gdyż chciał nadrobić rażące braki informacyjne w tym zakresie ${ }^{10}$.

${ }^{9}$ B. Koredczuk, Zainteresowania bibliograficzne..., s. 54.

${ }^{10}$ S. Kutrzeba, Jan Wincenty Bandtkie-Stężyński 1783-1846 [w:] Album biograficzny zastużonych Polaków i Polek wieku XIX, t. 2, Warszawa 1903, s. 223. 
Na studiach w Halle Bandtkie poznał Feliksa Bentkowskiego, wybitnego bibliografa i historyka literatury, który wkrótce zaproponował mu współpracę przy opracowywaniu Historii literatury polskiej. Bandtkie wyraził zgodę, bo w ten sposób chciał się odwdzięczyć swojemu protektorowi za polecenie go na lektora języka polskiego. Po przyjeździe do Warszawy w 1806 r. opracował rozdział dotyczący prawa, wykorzystując informacje zawarte w De studio iuris polonici. Znacznie je poszerzył i uzupełnił o nowszą literaturę. Materiał ten, pod nazwą Nauka prawodawstwa i prawnictwa polskiego, został opublikowany jako rozdział trzeci drugiego tomu Historii literatury polskiej (Wilno 1814) ${ }^{11}$. Był on jednym z najobszerniejszych w porównaniu z innymi, tj. filozofią, polityką, umiejętnościami matematycznymi, umiejętnościami lekarskimi czy teologią ${ }^{12}$. W Przedmowie do swego dzieła Bentkowski w pochlebnych słowach wypowiedział się o pracy Bandtkiego: „Naprzód oświadczam najczulszą wdzięczność mężom, którzy mi do niniejszego tomu pomocy swej łaskawie użyczyli. I tak Jan. Winc. Bantkie, Notariusz Xstwa Warszaw. jest autorem trzeciego rozdziału zawierającego literaturę prawniczą, którą w ten sposób ułożoną mi udzielił, iż ją całkiem do mojego zbioru wcieliłem, zastosowawszy ją tylko do ogółu, i poczyniwszy małe odmiany w wyrazach lub dodatki niektórych rzeczy" ${ }^{\prime 3}$. Dział prawniczy przygotowany przez Bandtkiego był więc już ukształtowaną bibliografią specjalną, aczkolwiek umieszczoną $\mathrm{w}$ ramach bibliografii ogólnej.

Przyjaźń z Bentkowskim pogłębiła zainteresowania Bandtkiego dziejami kultury polskiej i bardziej zbliżyła go do zagadnień związanych z rejestracją bibliograficzną świadectw tej kultury. Mimo że rozumiał on wagę rejestracji całego piśmiennictwa polskiego, to chciał ją ujrzeć także w postaci większego dzieła, które obejmowałoby jedną dziedzinę - prawo. Wiedział zapewne, że prace w takim kierunku prowadzili Konstanty Świdziński (w dziedzinie historii) i Michał Poliński (w naukach matematyczno-przyrodniczych).

W kolejnych latach Bandtkie kontynuował prace bibliograficzne, koncentrując się głównie na przygotowaniu retrospektywnej bibliografii prawa polskiego. Przypuszczalnie była ona gotowa w $1824 \mathrm{r}^{14}$, skoro J. Zawadzki, który nabył prawo do wydania drugiej edycji Historii literatury polskiej Bentkowskiego, zwrócił się listownie do Bandtkiego w październiku tego samego roku z prośbą o przysłanie rękopisu dotyczącego literatury prawniczej. Pisał on: „Będzie on nam służyć za

${ }^{11}$ F. Bentkowski, Historia literatury polskiej, t. 2, Warszawa-Wilno 1814, cz. 3 [Umiejętności], rozdz. 3, s. 115-294.

12 B. Koredczuk, Polska bibliografia historycznoprawna. Początki, rozwój i stan obecny, „Acta Universitatis Wratislaviensis" No 2616, Prawo 288, Wrocław 2004, s. 407.

${ }^{13}$ F. Bentkowski, Historia literatury..., s. III.

14 W Bibliografii literatury polskiej „Nowy Korbut”, t. 4, s. 221 podany jest rok 1825 i błędne miejsce powstania bibliografii - Kraków zamiast Warszawy. 
wzór, jak mamy inne oddziały literatury urządzać. Słuszną jest rzeczą abyś W[ielce] $\mathrm{W}$ [ielmożny] M[ości] P[anie] D[obrodzieju], miał prawo dysponowania swoją pracą, przeto też nic w jego rękopisie odmieniać nie będziemy; oprócz zaś całkowitych egz[emplarzy] powt[órnie] wyd[anej] [Historii] literatury polskiej, które pozwolisz sobie ofiarować, czekać będę jego rozkazu, wiele mam egz[emplarzy] wybić oddzielnie samej literatury prawniczej...”"15. Dwa lata później Zawadzki w liście do Józefa Węckiego, który zarządzał filią jego firmy w Warszawie, narzekał, że Bandtkie może swojego manuskryptu nie dać ${ }^{16}$, a ,jest to zło wielkie, bo będziemy musieli część prawną tak wydrukować, jak była w I edycji..."”17.

Według Bibliografii literatury polskiej „Nowy Korbut” dzieło Bandtkiego nosiło tytuł Bibliografia prawa polskiego od najdawniejszych czasów do roku $1823^{18}$. Prawdziwość tej informacji budzi duże wątpliwości co najmniej z trzech powodów. Po pierwsze, we „Wstępie” do Bibliografii Bandtkie nazywa swoje dzieło „katalogiem”. Po drugie, termin „bibliografia” w znaczeniu „spis ksiąg” był w tym czasie stosunkowo rzadko używany; w Polsce jedynym do 1830 r. dziełem określanym tym terminem była Jana Daniela Janockiego Bibliographia Zalusciana (1763-1766). Po trzecie, Bibliografia nie jest autografem, co potwierdza widniejący na karcie tytułowej napis „Dzieło pogrobowe”. Wszystkie te wątpliwości rozwiewa zaś porównanie tekstu bibliografii z autografami J.W. Bandtkiego. A skoro nie zachowała się karta tytułowa rękopisu autorskiego, to nie wiadomo, jaki tytuł dał swemu dziełu Bandtkie. Do drugiej edycji Historii literatury polskiej nie doszło m.in. z powodu śmierci Ludwika Sobolewskiego, redaktora nowego wydania dzieła Bentkowskiego, a później wybuchu powstania listopadowego i represji, jakie po nim nastąpiły.

Po zamknięciu Uniwersytetu Warszawskiego w 1831 r. Bandtkie wycofał się z pracy naukowej, oddał się wyłącznie praktyce sądowej jako pisarz aktowy, czyli notariusz ${ }^{19}$. Jak pisze Emil Kierski: „Nic więcej już nie pisał, lecz tylko wydawał, co już miał napisane" ${ }^{20}$. Następne lata przyniosły falę wzmożonego ucisku naro-

15 List Józefa Zawadzkiego do J.W. Bandtkiego z 20 października 1824 r. [w:] T. Turkowski, Materiaty do dziejów literatury i oświaty z archiwum drukarni i księgarni Józefa Zawadzkiego w Wilnie, t. 2, Wilno 1937, s. 248.

${ }^{16}$ Zawadzki donosił, że Bandtkie był bardzo niezadowolony, że musi zwrócić rękopis „Statutów" ich właścicielowi - Chreptowiczowi [prawdopodobnie chodzi o Andrzeja Chreptowicza (1768-1844) - zbieracza książek, bibliofila]. Próba odkupienia przez Zawadzkiego rękopisu nie powiodła się i właściciel zażądał jego oddania. List J. Zawadzkiego do J. Węckiego w Warszawie z 22 czerwca (4 lipca) 1826 r. Ibidem, s. 248.

17 Ibidem.

18 Bibliografia literatury polskiej „,Nowy Korbut”, t. 4, s. 221.

19 W.A. Maciejewski, Nekrolog Jana Stężyńskiego Bandtkiego, „Biblioteka Warszawska” 1846, t. 1 , s. 615 .

${ }^{20}$ E. Kierski, Jan Wincenty Bandtkie-Stężyński, „Tygodnik Ilustrowany” 1864, nr 243, s. 185. 
dowego. W tej sytuacji Bandtkie nie mógł już myśleć o wydaniu swojego dzieła bibliograficznego, które miało wydźwięk patriotyczny i polityczny.

Mimo to nie odmówił udziału w pracach związanych z drugim wydaniem dzieła Bentkowskiego, które na nowo podjął J. Zawadzki. Być może uczynił to ze względu na Bentkowskiego, który w 1837 r. wrócił do tej sprawy, powołując się na dobro publiczne ${ }^{21}$. Nadarzyła się też wtedy okazja do ogłoszenia drukiem materiałów zgromadzonych przez niego samego. Przygotowania do nowej edycji Historii literatury polskiej prowadził również hr. Edward Raczyński, a wyznaczony przez niego redaktor korzystał z pomocy wielu uczonych, m.in. J.W. Bandtkiego ${ }^{22}$. Zwrócił się on do Zawadzkiego z propozycją nabycia praw i materiałów do drugiej edycji dzieła Bentkowskiego. W tej sytuacji Zawadzki raz jeszcze podjął wyzwanie społeczne i obiecał nowe wydanie Historii. Projektowana bibliografia narodowa początkowo miała nosić tytuł Bibliografia polska, jednak licząc na większe zainteresowanie publiczności, postanowiono zrezygnować $\mathrm{z}$ tego tytułu na rzecz następującego: Obraz bibliograficzno-historyczny literatury i nauk w Polsce od wprowadzenia do niej druku po rok 1830 włacznie, z pism Janockiego, Bentkowskiego, Ludwika Sobolewskiego, Ossolińskiego, Jana Winc. i Jerz. Bandtków itd.

W 1838 r. Adam Zawadzki w imieniu ojca zakupił od Bandtkiego materiały bibliograficzne dotyczące prawa polskiego do $1837 \mathrm{r}$. za sumę 400 złotych polskich; miała być ona wypłacona w postaci wybranych przez bibliografa dzieł polskich, własnego, jak też obcego nakładu, znajdujących się w księgarni J. Zawadzkiego i Węckiego w Warszawie ${ }^{23}$. Z przedmowy do Obrazu autorstwa A. Zawadzkiego, napisanej w 1840 r., a więc dwa lata po dokonaniu transakcji, dowiadujemy się, że zakupiony rękopis nosił tytuł Historia i bibliografia prawa polskiego ${ }^{24}$. Niewątpliwie tytuł ten pochodził od samego Bandtkiego; pojawia się tu termin „bibliografia”, co dowodzi, że był on w tym czasie dość powszechnie stosowany na określenie spisu książek. Fakt ten dostarcza ważnej informacji o tym, jak kształtował się na późniejszych etapach tytuł rękopisu. Z listu J. Zawadzkiego do Adama Jochera, redaktora przyszłej bibliografii, wynika, że zakupiony rękopis był rozszerzoną i uzupełnioną o nową literaturę wersją rozdziału z bibliografii Bentkowskie-

${ }^{21}$ A. Kłossowski, Księgarze i bibliografia. Dzieje wydawnicze Obrazu, „Księgarz” 1977, nr 1, s. 56.

${ }^{22}$ Ibidem.

${ }^{23}$ Umowa J.W. Bandtkiego z Adamem Zawadzkim z 28 V 1838 r. [w:] T. Turkowski, Materiaty do dziejów literatury $i$ oświaty z archiwum drukarni i księgarni Józefa Zawadzkiego w Wilnie, t. 2, Wilno 1937, s. 262.

${ }^{24}$ Pisał on: ,[...] udało się nabyć w Warszawie szacowny rękopis uczonego Jana Win. Bantkie Historię i bibliografie prawa polskiego". A. Zawadzki, Od wydawców [w:] A. Jocher, Obraz bibliograficzno-historyczny literatury i nauk w Polsce od wprowadzenia do niej druku po rok 1830 włącznie, z pism Janockiego, Bentkowskiego, Ludwika Sobolewskiego, Ossolińskiego, Jana Winc. i Jerz. Bandtków itd., t. 1, Wilno 1840, s. VII. 
go $^{25}$. Jednocześnie Zawadzki donosił, że zakupione materiały są „tak porządnie [sporządzone], że prosto przepisywać nie trzeba"26.

$\mathrm{Z}$ powodu różnych trudności, m.in. $\mathrm{z}$ winy samego Jochera, publikację Obrazu zakończono na trzecim tomie (Wilno 1839-1857). Tom pierwszy objął literaturę i filologię starożytną oraz nauki razem wzięte, zbiory, poligrafię; tom drugi i trzeci - teologię. Materiały obejmujące pozostałe działy nauki - w tym dział piąty, zawierający bibliografię prawa przygotowaną przez Bandtkiego - nie ukazały się drukiem.

Po śmierci J.W. Bandtkiego w 1846 r. całą jego spuściznę rękopiśmienną odziedziczył jego syn, Kazimierz Bandtkie-Stężyński ${ }^{27}$. Bezzwłocznie podjął on starania o publikację dzieł ojca. Własnym nakładem wydał m.in. w $1850 \mathrm{r}$. Historię prawa polskiego napisana $i$ wyktadana przed $r .1830 \mathrm{w}$ b. Warszawskim Aleksandryjskim Uniwersytecie, a rok później Prawo prywatne polskie napisane i wykladane przed r. 1830 w b. Warszawskim Aleksandryjskim Uniwersytecie.

Równocześnie K. Bandtkie podjął starania o wydanie retrospektywnej bibliografii prawniczej. Przygotował dzieło do druku, wykorzystując do tego materiały pozostawione przez ojca. Niestety, nie włożył w to zbyt wiele wysiłku i świadomej pracy i poszedł po linii najmniejszego oporu. Na podstawę publikacji złożyły się: nadbitka rozdziału dotyczącego prawa z Historii literatury polskiej Bentkowskiego (doprowadzony do 1812 r.) z poprawkami naniesionymi przez J.W. Bandtkiego oraz jego autograf, zawierający dość liczne uzupełnienia za poprzednie lata (sprzed 1812 r.) i materiały bibliograficzne za lata 1813-1823. Autograf liczy 555 kart i zawiera 175 ponumerowanych pozycji. Każda z nich została oznaczona literą i cyfrą, np. A1, P2, A3, L4, gdzie litera miała oznaczać jakiś klucz rzeczowy, a cyfra numer pozycji (ostatnia pozycja ma przyporządkowany symbol G175). Symbole te zostały dopisane w nadbitce na marginesie, w miejscu, w którym miała być wpisana dana pozycja bibliograficzna. Rola K. Bandtkiego w przygotowaniu rękopisu do druku sprowadziła się de facto do graficznego wyróżnienia pewnych elementów tekstu przez podkreślenie ich niebieskim i czerwonym atramentem, sporządzenia uwag dla zecera $^{28}$ oraz niekiedy poprawienia i wygładzenia tekstu pod względem językowym.

${ }^{25}$ List Józefa Zawadzkiego do Adama Jochera z 31 V 1838 [w:] T. Turkowski, Materiaty do dziejów literatury i oświaty..., t. 2, s. 262.

${ }^{26}$ Ibidem.

${ }^{27}$ Kazimierz Bandtkie-Stężyński (1813-1876) - urzędnik bankowy, numizmatyk, autor Numizmatyki krajowej (t. 1-2, Warszawa 1839-1840), urzędnik Heroldii, uczestnik czwartków numizmatycznych, tj. spotkań miłośników dawnych monet i medali; wydawca dzieł ojca, Jana Wincentego Bandtkiego.

28 „Panie Zecer! Wszystko co jest podkreślone czerwonym atramentem zamieścić w przypisie pod kolumnami. Gdzie jest odsyłacz oznaczony literą i liczbą szukać przypisu w rękopiśmie pod tymi znakami i układać go jak tekst aż do następnej strony. Wszystko co określone niebieskim atramentem układać literami cursive". 


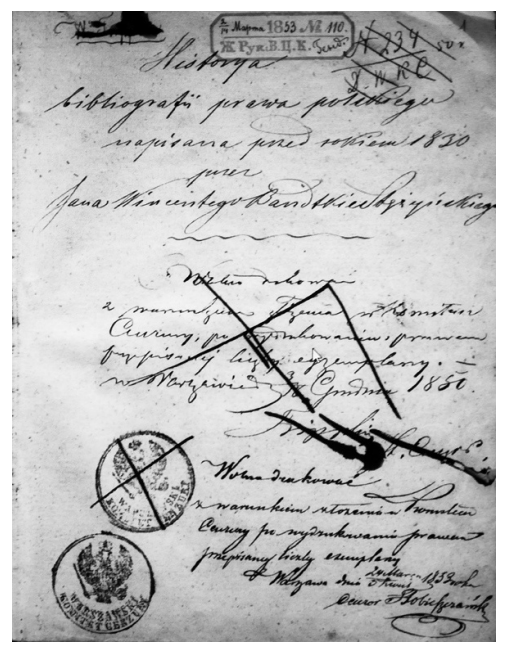

Fot. 2. Karta tytułowa rękopisu Historia bibliografii prawa polskiego napisana przed rokiem 1830 Jana W. Bandtkie-Stężyńskiego

Źródło: zbiory Biblioteki Jagiellońskiej, sygn. 5760.

Zaopatrzył on także rękopis w kartę tytułową, na której widnieje tytuł Historia bibliografii prawa polskiego napisana przed rokiem 1830 przez Jana Wincentego Bandtkie-Stężyńskiego. Przypuszczalnie K. Bandtkie wziął go z bibliografii przygotowanej przez jego ojca dla Zawadzkiego. Zmodyfikował go jednak: zachował te same słowa: „historia” i „bibliografia”, ale pominął spójnik „i”. Wydaje się, że tak zdefiniowany tytuł był lepiej dopasowany do treści dzieła, w którym chodziło o wykazanie historycznego rozwoju piśmiennictwa prawniczego, a fakt, że bibliografia ograniczała się do rejestracji piśmiennictwa prawniczego wydanego do 1823 r. (czyli trzydzieści lat przed przygotowaniem do druku tej bibliografii), tym bardziej wskazywał na historyczny charakter.

Tak przygotowany rękopis Historii bibliografii prawa polskiego został skierowany do publikacji, o czym świadczy zapis dokonany na karcie tytułowej: „z aprobatami cenzury rosyjskiej w Warszawie $3 / 18$ grudnia 1850 . Tripplin, starszy cenzor" i dopisek „Warszawa dnia 24 marca/5 kwietnia 1853 roku cenzor Sobieszczański”229. Badacze przez wiele lat byli przekonani (dotyczy to zresztą także piszącej te słowa), że druk dzieła rozpoczęto, o czym miała świadczyć zachowana część wydruku próbnego, obejmująca 180 stron z naniesioną korektą (strony 115-294) ${ }^{30}$. Jak się okazuje, ta opinia była błędna - rzekomy wydruk to nic innego jak wspomniana wcześniej nadbitka rozdziału prawniczego z Historii literatury polskiej Bentkow-

${ }^{29}$ Inwentarz rękopisów Biblioteki Jagiellońskiej: nr 4175-6000, oprac. W. Wisłocki, Kraków 1938, s. 467.

${ }^{30}$ J. Ender, Bandtkie-Stężyński..., s. 30; B. Koredczuk, Udziat inteligencji prawniczej..., s. 261. 


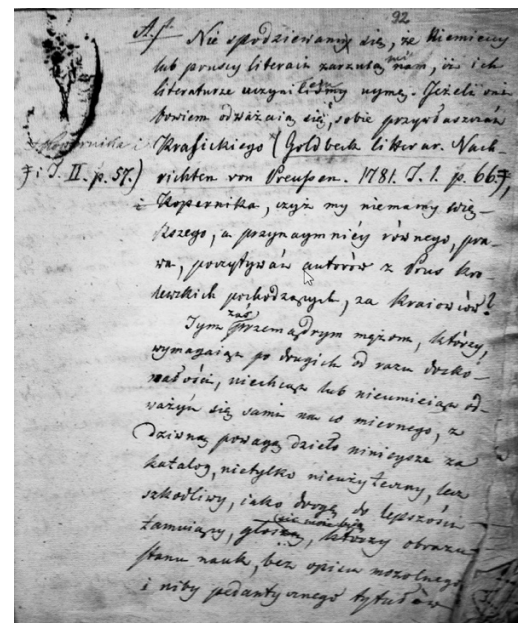

Fot 3. Karta z autografu Historia bibliografii prawa polskiego napisana przed rokiem 1830 Jana W. Bandtkie-Stężyńskiego

Źródło: zbiory Biblioteki Jagiellońskiej, rkp. sygn. 5760.

skiego, z dopiskami naniesionymi przez J.W. Bandtkiego i jego syna. Wszystko wskazuje na to, że do druku bibliografii jednak nie doszło. Prawdopodobnie uznano, że rękopis w takiej postaci nie nadaje się do bezpośredniego wykorzystania przez zecerów. Żeby stanowił on dzieło zwarte, o jednolitej koncepcji, wymagał gruntownych przeróbek. Wiązało się to z koniecznością scalenia materiału bibliograficznego, jego uporządkowania i przedstawienia w czytelnej formie. Owiana tajemnicą jest droga, jaką rękopis Historii bibliografii prawa polskiego dotarł do zbiorów Biblioteki Jagiellońskiej. Wiadomo tylko, że był on darem senatu akademickiego z $1896 \mathrm{r}^{31}$

Pomimo niepowodzenia w tej materii K. Bandtkie nie porzucił myśli o wydaniu pracy ojca. Potwierdzeniem tego jest wzmianka zawarta w notce o J.W. Bandtkiem pióra Emila Kierskiego, pochodząca z 1864 r. Dowiadujemy się z niej, że „Kazimierz Bandtkie posiada przygotowany już zupełnie do druku rękopis ojca p.n. Bibliografia prawa polskiego od najdawniejszych czasów do roku 1823 składający się z 604 stronic in folio, który pierwiastkowo miał być wcielony do nieukończonego Obrazu bibliograficznego Jochera, a dziś oczekuje pomyślniejszej dla piśmiennictwa chwili, aby w osobnym pojawić się wydaniu"32. Takie szczegółowe informacje o rękopisie, jak: tytuł, objętość i format, dowodzą, że Kierski pozyskał je od samego K. Bandtkiego. Warto zwrócić uwagę, że pierwotny tytuł rękopisu uległ zmianie. Prawdopodobnie wynikało to z faktu, iż od połowy XIX w. zaczął

${ }^{31}$ Inwentarz rękopisów Biblioteki Jagiellońskiej..., s. 468.

${ }^{32}$ E. Kierski, Jan Wincenty Bandtkie-Stężyński, s. 185. 


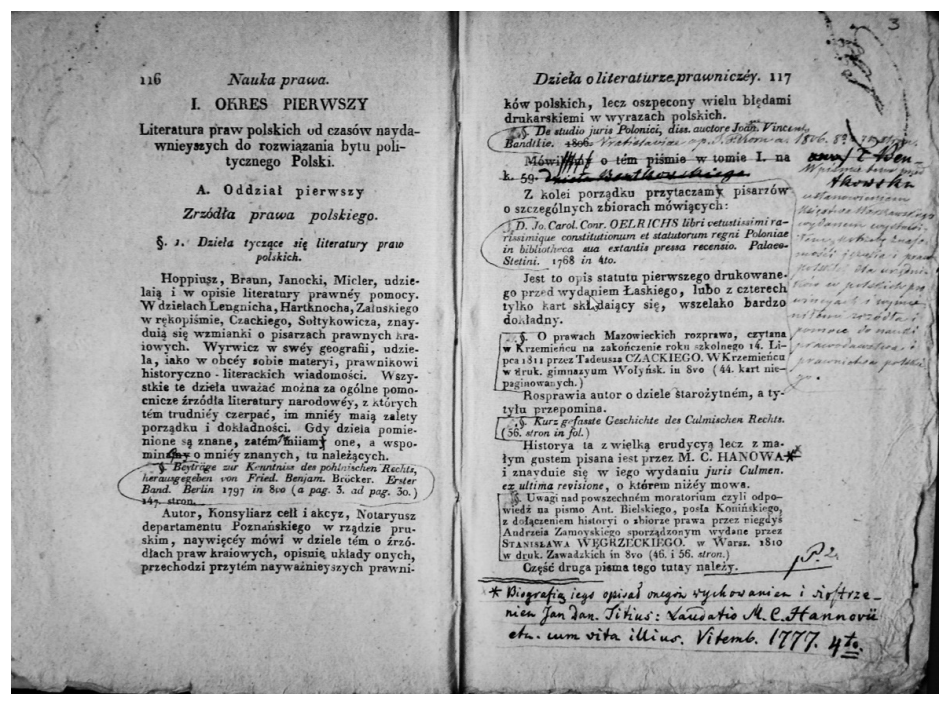

Fot. 4. Nadbitka rozdziału prawniczego z Historii literatury polskiej Feliksa Bentkowskiego z poprawkami i korektą naniesionymi przez Jana W. Bandtkiego Źródło: zbiory Biblioteki Jagiellońskiej, rkp. sygn. 5760.

się upowszechniać termin „bibliografia” i coraz częściej występował na kartach tytułowych dzieł bibliograficznych. Zapewne po to, by być w zgodzie z nowymi trendami, K. Bandtkie przeredagował tytuł rękopisu, uzupełniając go informacją o zasięgu czasowym dzieła. Jednocześnie dołożył wszelkich starań, by zostało ono rzetelnie przygotowane, spełniało wymogi redakcyjne i wydawnicze stawiane pracom bibliograficznym. Niestety, także i tym razem do druku bibliografii nie doszło. Niewątpliwie wpłynęła na to sytuacja polityczna po powstaniu styczniowym i związane $\mathrm{z}$ nią represje.

A teraz kilka słów o rękopisie Bibliografii, jego strukturze i zawartości. Pełny tytuł dzieła brzmi: Bibliografia prawa polskiego od najdawniejszych czasów do roku 1823, napisana przez Jana Wincentego Bandtkie-Stężyńskiego, Radcę Stanu, Członka Komisji Rządowej Sprawiedliwości, etc., etc., etc. Dzieło pogrobowe. Rękopis liczy 649 stron ponumerowanych w lewym lub prawym górnym rogu. Składa się z następujących części: karty tytułowej, wstępu (siedem nieponumerowanych stron), zrębu głównego (s. 8-604), czterech nieponumerowanych kart ze spisem rzeczy (w prawym górnym rogu widnieje napis: strona), karty z napisem: „Spis rzeczy szczegółowych porządkiem alfabetycznym” (s. 609) oraz części pt. „Przypisy do załączenia pod kolumnami gdzie wypada”, która ma odrębną numerację (s. 1-40).

Już na pierwszy rzut oka widać, że całe dzieło zostało sporządzone jednym charakterem pisma. Można sądzić, że wyszło ono spod ręki K. Bandtkiego. Dowodem na to jest, że tym samym charakterem pisma naniesiono korektę w rękopisie 
Historii bibliografii oraz zmiany we wstępie do Bibliografii. Raczej mało prawdopodobne jest, aby poprawki stylistyczne, językowe i pewne zmiany merytoryczne polegające na przestawieniu niektórych fragmentów naniosła osoba nieobeznana z systemem pracy i językiem J.W. Bandtkiego. Rękopis został sporządzony pismem czytelnym i starannym, odczytanie tekstu nie sprawia trudności, po jego lewej stronie pozostawiono wąski margines. Widać, że autorowi zależało na estetyce pisma. W tekście zastosowano też wiele wyróżnień. Nazwy głównych działów podkreślono potrójną linią ciągłą, nagłówki kolejnych poddziałów wyróżniono przez zastosowanie podwójnej i pojedynczej linii ciągłej. Również opisy bibliograficzne książek oraz tytuły artykułów wyróżniono pojedynczą linią ciągłą. U góry strony, na której zaczyna się wstęp, znajduje się notka dla zecera: „Panie Zecer! Wszystko co podkreślone niebieskim lub czarnym atramentem układać odmiennym, mniejszym drukiem jak tekst". Wszystko wskazuje na to, że pod względem typograficznym Bibliografia miała być wzorowana na rozdziale prawniczym Historii literatury polskiej Bentkowskiego. Tak więc opisy książek i tytuły artykułów planowano składać mniejszą czcionką niż adnotacje. Pozycje bibliograficzne są ponumerowane - jest ich 899 . Numery umieszczono zaś na lewym marginesie, na zewnątrz opisu bibliograficznego.

Bibliografię Bandtkiego, choć zachowała się tylko w rękopisie, należy uznać za pierwszą polską bibliografię z dziedziny prawa. Chronologicznie wyprzedza ona znacznie pierwszą tego typu drukowaną pracę adwokata Adolfa Suligowskiego pt. Bibliografia prawnicza polska XIX i XX wieku. Poprzedzona stowem wstepnym i rzutem oka na twórczość piśmiennicza prawników polskich w ciagu XIX i pierwszego dziesięciolecia XX wieku (Warszawa 1911) ${ }^{33}$. Praca Bandtkiego była nowatorska, głównie ze względu na swój zakres. Była to pierwsza samoistna bibliografia, która rejestrowała tylko polskie piśmiennictwo prawnicze. W tym czasie wykazy literatury prawniczej nie pojawiały się samodzielnie, lecz występowały w obrębie bibliografii o charakterze ogólnym ${ }^{34}$.

Warunkiem, jaki Bandtkie stawiał bibliografii, była jej kompletność. Wynikało to przede wszystkim z pobudek patriotycznych, ale także z potrzeb historii prawa. Ten praktyczny wymiar dzieła wyraził autor w następujących słowach we „Wstępie” do Bibliografii: „Katalog ten może służyć do wyobrażeń ogólnych i wielkich w oka mgnieniu za odczytaniem wygodnym kilku wierszy lub kart nabyć się mogących, lecz i nieomylne, że jak napisy pogrobowe do historii, jak cegła do budowli, tak tytuły dzieł do obrazu literatury za bardzo użyteczne, a podług zdania wielu uczonych nawet konieczne, potrzebne" ${ }^{35}$.

${ }^{33}$ B. Koredczuk, Udziat inteligencji prawniczej..., s. 262.

${ }^{34}$ B. Koredczuk, Zainteresowania bibliograficzne..., s. 52-54.

35 J.W. Bandtkie-Stężyński, Wstęp [w:] Bibliografia prawa polskiego od najdawniejszych czasów do roku 1823, s. [2-3]. 
W stosunku do rozdziału prawniczego opublikowanego w 1814 r. w Historii literatury polskiej Bentkowskiego Bibliografia stanowiła właściwie zupełnie nowe dzieło, gdyż została znacznie uzupełniona o nowe materiały bibliograficzne, a przede wszystkim wzbogacona literaturą prawniczą z lat 1814-1823. Miała też nieco odmienne zasady doboru, opisu i układu materiału.

Oczywiście główna zasada doboru materiału do Bibliografii pozostała taka sama, jak w rozdziale prawniczym. Autor wykazuje prace autorów polskich lub pochodzenia polskiego, piszących w języku polskim bądź w innych językach, wydane w kraju i za granicą. Bandtkie uwzględnił również prace autorów śląskich i pruskich, uważając związek Śląska i Prus z Polską za nierozerwalny tak na płaszczyźnie politycznej, jak i naukowej. Motywował to w następujący sposób: „Okoliczność ta, że umieszczać będę pisarzów także obcych, szczególnie śląskich i pruskich, zwłaszcza w związku niejakim w prawodawstwie naszym zostających, nie potrzebuje zapewne usprawiedliwienia. Bo który nie był świadomym związków politycznych i naukowych między owymi krajami a Polską dawniej zachodzących, tym samem wyznać by musiał, że sędzią w tej sprawie niewłaściwym. Nie spodziewam się, że niemieccy lub pruscy literaci zarzucą mi, iż ich literaturze uczyniłem ujmę. Jeżeli bowiem odważają się przywłaszczyć sobie Kopernika i Krasickiego, czy innych nieznanych większych, a przynajmniej równego prawa, poczytnych autorów z Prus Królewskich pochodzących, za krajowców”. Na marginesie dopisano jeszcze: ,że obejmujemy w tomie dzieła takie autorów Prus Królewskich, nikt za pisarzy i za ziomków nazwanych, tego nie zgoni kto przekonany, że Kopernik, Steiner, Linde mają na zasadzie dawnego związku politycznego ich kraju z Polską właściwą i na zasadzie swych zasług niezaprzeczalne prawo współobywatelstwa Polskiego" 36 .

Nieco inny niż w rozdziale prawniczym był w Bibliografii zasięg wydawniczo-formalny - zawiera ona nie tylko wydawnictwa samoistne pod względem wydawniczym i piśmienniczym (książki), lecz także artykuły z czasopism, rozprawy z dzieł zbiorowych, recenzje. Warto podkreślić, że poszerzenie tego zasięgu o utwory niesamoistne wydawniczo było decyzją raczej pionierską, ponieważ dopiero w latach 60. XIX w. materiały z czasopism zaczęto uwzględniać w pierwszych polskich bibliografiach dziedzinowych. Jeśli chodzi o kryterium formy piśmienniczej, to w Bibliografii ujęto: zbiory uchwał, ustawy i statuty. Miała być ona spisem kompletnym, obejmującym całe polskie piśmiennictwo prawnicze, nie tylko prace ogłoszone drukiem, ale też pozostające $\mathrm{w}$ rękopisie.

Ustalenie zasięgu chronologicznego dzieła Bandtkiego nie przedstawia większych trudności. Pod tym względem jest ono bibliografią retrospektywną, ponie-

\footnotetext{
${ }^{36}$ Ibidem, s. [5-6].
} 


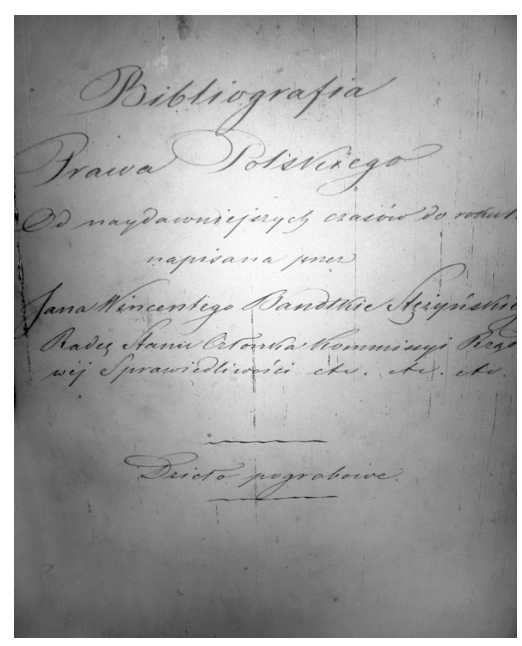

Fot. 5. Strona tytułowa rękopisu Bibliografia prawa polskiego od najdawniejszych czasów do roku 1823 napisana przez Jana Wincentego Bandtkie-Stężyńskiego

Źródło: zbiory Biblioteki Jagiellońskiej, sygn. 4917;

Biblioteka Narodowa, mikrofilm sygn. 51252.

waż dotyczy zamkniętego i ściśle oznaczonego okresu historycznego - obejmuje piśmiennictwo prawnicze od czasów najdawniejszych do $1823 \mathrm{r}$.

Przy zbieraniu materiałów do Bibliografii Bandtkie korzystał w pierwszym rzędzie z własnego księgozbioru, w którym znajdowało się wiele cennych wydawnictw z zakresu historii i prawa polskiego, zwłaszcza mało znanych rękopisów, w tym rękopiśmiennych kodeksów na pergaminie ${ }^{37}$. Miał on w swoich zbiorach także ważniejsze czasopisma wychodzące na obszarze trzech zaborów, jak: „Themis Polska”, „Pamiętnik Warszawski” czy „Kwartalnik Naukowy”. O charakterze tych zbiorów zdecydowały jego własne zainteresowania naukowe i zamiłowania bibliofilskie, oparte na szerokiej znajomości bibliografii. Dzięki ogromnej pasji kolekcjonerskiej Bandtkie stworzył jeden z największych prywatnych księgozbiorów o profilu historyczno-prawnym na terenie Królestwa Polskiego ${ }^{38}$. Prawdopodobnie także swoje prywatne zbiory udostępnili mu znakomici zbieracze piśmiennictwa z zakresu prawa: Joachim Lelewel, Jan Olrych Szaniecki, Konstanty Świdziński. Dzięki temu przy opisywaniu dzieł Bandtkie w znacznej mierze opierał się na autopsji.

Oczywiście materiał do Bibliografii czerpał również z drukowanych źródeł bibliograficznych. Były to przede wszystkim bibliografie ogólne: Szymona Staro-

${ }^{37}$ B. Koredczuk, Zainteresowania bibliograficzne..., s. 57-59; Katalog Biblioteki pozostałej po ś.p Janie Wincentym Stężyńskim Bandtkie. Radcy Stanu Członka Komisji Rzadkowej Sprawiedliwości, wydał i słowo wstępne napisał Cz. Erber, Kielce 2000.

${ }^{38}$ E. Słodkowska, Biblioteki w Królestwie Polskim 1815-1830, Warszawa 1996, s. 170-171. 
wolskiego Scriptorum Polonicorum Hecatontas (1625), Jana Daniela Janockiego Janociana (1776-1816), Polonia litterata nostri temporis (1750), Józefa Maksymiliana Ossolińskiego Wiadomości historyczno-krytyczne, Feliksa Bentkowskiego Historia literatury polskiej (1814), Adama Tomasza Chłędowskiego Spis dziet polskich opuszczonych lub źle oznaczonych w Bentkowskiego Historii literatury polskiej, zebrany i drukiem ogłoszony (1818); także pierwsze bibliografie dziedzinowe: Samuela Hoppiusa De scriptoribus historiae Polonicae (1707), Dawida Brauna De scriptorum Poloniae et Prussiae historicorum, politicorum et juris... (1723), Józefa Andrzeja Załuskiego Bibliografia historyków, prawników, polityków (1823) oraz bibliografie osobowe, np. Alojzego Osińskiego O życiu i pismach Tadeusza Czadzkiego (1816). Ponadto Bandtkie przejrzał m.in. Voluminum Legum, Tadeusza Czackiego O litewskich i polskich prawach (t. 1-2, 1800-1801), Jerzego Samuela Bandtkiego Historię drukarń krakowskich (1815) i wiele innych prac, natomiast z czasopism np. „Pamiętnik Warszawski”, „Dziennik Wileński” oraz wydawnictwo urzędowe „Dziennik Praw” (Księstwa Warszawskiego).

Najważniejsze z punktu widzenia metodyki bibliograficznej jest to, że Bandtkie starał się wszystkie opisywane dzieła zobaczyć na własne oczy. W przypadku trudności z dotarciem do danych książek poprzestawał na autorytecie autorów, którzy o nich pisali bądź wzmiankowali je w nawiasie. Zastosował jednak pewne stopniowanie tych źródeł bibliograficznych. Największą wiarę w tej materii dawał Janockiemu i Ossolińskiemu, którzy pisząc o jakimś dziele, zaznaczali, czy mieli je w ręku, czy znali tylko z czyichś opisów. Bandtkiemu udało się wielokrotnie sprostować błędy, które wielu badaczy przed nim - ponieważ nie sięgali do samego źródła - powtarzało. Niemałą jego zasługą było także odkrycie nazwisk wielu autorów, którzy wydali swe dzieła bezimiennie.

Opisy bibliograficzne pozycji w Bibliografii Bandtkiego są sporządzone z dużą starannością. Jeśli chodzi o dzieła drukowane, to opis - odtwarzający dokładnie kartę tytułową - obejmuje następujące elementy: tytuł, nazwę autora, numer tomu, oznaczenie wydania, miejsce wydania, nazwę drukarni, rok wydania, format, liczbę stron.

Np. (414) Prawo pospolite Królestwa Polskiego przez Gotfryda Lengnicha po łacinie zebrane przetłumaczone po polsku przez X. Marcina Moszczeńskiego profesora retoryki i prefekta Szkół Rzeszowskich Schol. Piar. T. II 1760 w Krakowie w Druk. Stanisł. Stachowicza in $8^{\circ}$ 909, 649 i 193 stron.

Jeśli chodzi o adres wydawniczy, Bandtkie przytacza miejsce i rok druku oraz nazwę drukarni lub informuje, że dane dzieło ukazało się bez miejsca czy roku wydania albo bez jednego i drugiego. Czasami podaje przybliżoną datę ukazania się dzieła lub stawia przy niej znak zapytania, jeżeli jest ona niepewna.

Przy większości opisów Bandtkie powołuje się na bibliografie i inne publikacje, w których umieszczone zostały już wcześniej wymienione przez niego teraz 
pozycje. Świadczyło to o jego wielkiej erudycji i szacunku do czytelnika. Warto zauważyć, że było to wówczas posunięcie nowatorskie, metodę tę zastosował bowiem na szerszą skalę dopiero A.B. Jocher w swej bibliografii pt. Obraz bibliograficzno-historyczny literatury i nauk w Polsce. W rękopisie na końcu opisu umieścił on odnośnik cyfrowy kierujący do części „Przypisy do załączenia pod kolumnami gdzie wypada”, w której podane jest źródło, z którego pochodzą informacje o druku (nazwisko autora lub tytuł w skrócie, numer tomu oraz odpowiednia strona).

Dzieła anonimowe, o nieustalonym autorstwie, Bandtkie opisuje w dziale „Pisarze prawni” pod określeniem „Bezimiennego”, natomiast w opisie dzieł swojego autorstwa w nawiasie, po tytule, zamieszcza informację ,napisana przeze mnie".

Np. poz. 371. Bezimiennego. Krótki wywód że Prusy nie są obowiązane do pospolitego ruszenia bez miejsca i roku in 4 to.

Np. (34) Zbiór rozprawa o przedmiotach prawa polskiego (napisany przeze mnie) w Warszawie i Wilnie 1812 r. nakładem i drukiem Józefa Zawadzkiego in $8^{\circ}$.

Przy publikacjach z czasopism opis zawiera tytuł, autora i cytatę wydawniczą (tytuł czasopisma, rok, tom, numer) oraz zakres stron, które zajmuje utwór.

Np. poz. 38. Rzecz historyczna o notariacie czyli pisarstwie aktowym krajowym, tak dawniejszym jako i nowszem, czytana na publicznem posiedzeniu szkoły prawa i administracji w Warszawie w paździer. 1815 przeze mnie.

Znajduje się w Pamiętniku Warszawskim II s. 324-347 i w numerze 12 s. 413-444.

Opisy rękopisów zawierają następujące elementy: tytuł, autor, format, czas powstania, lokalizacja rękopisu. W przypadku listów podany jest nadawca i odbiorca, miejsce i data napisania listu oraz jego format.

Np. poz. 171. Zbiór rękopiśmienny praw Mazowieckich przez Stefana proboszcza Kolegiaty Warszawskiej, Kanonika Katedry Płockiej Bolesława ułożony znajdował się także w bibliotece Załuskich pod numer 1995 z napisem: Statuty Ducum Mazovie, a Stefani etc. Varsoviae a 1483 collecta in 4 ty.

Opis zasadniczy uzupełniał Bandtkie często adnotacjami, w których podawał dodatkowe informacje dotyczące szczegółów druku, próbował ustalić autora, miejsce i rok wydania, jeśli nie było to podane na karcie tytułowej, informował o rzadkości druku, jego lokalizacji, materiale ilustracyjnym (drzeworyty, herby), różnicach między egzemplarzami oraz zamieszczał uwagi o treści, walorach dzieła, a niekiedy także jego ocenę. 


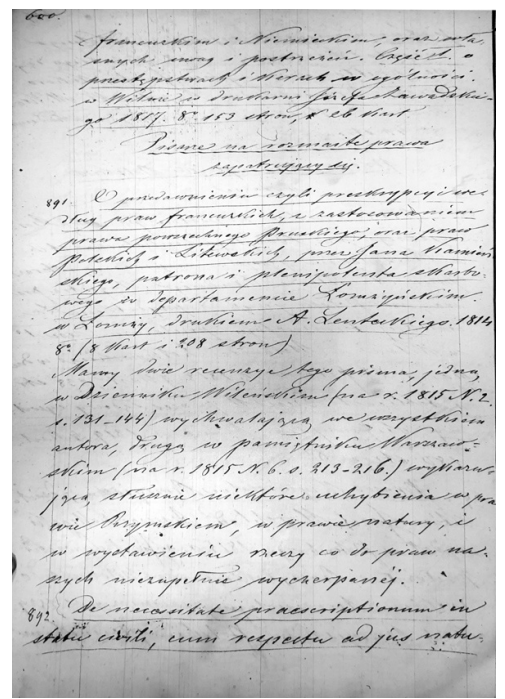

Fot. 6. Strona rękopisu Bibliografia prawa polskiego od najdawniejszych czasów do roku 1823 napisana przez Jana Wincentego Bandtkie-Stężyńskiego

Źródło: zbiory Biblioteki Jagiellońskiej, sygn. 4917;

Biblioteka Narodowa, mikrofilm sygn. 51252.

Informując o treści druku lub rękopisu, Bandtkie postępuje w różny sposób. Nieraz w kilkuwyrazowej notatce podaje krótko temat dzieła, jak np. w poz. 394 „Jus Regni Poloniae ex statutis...” M. Jun. Bogum. Meistera: „W tomie pierwszym jest wyłożone prawo publiczne, a w drugim prawo prywatne cywilne Polskie wszelkiego rodzaju. Dzieło to przed Czackim najuczeńsze, u Prusaków było w wielkim poważaniu". W niektórych przypadkach zamieszcza tytuły części składowych dzieła, jak np. w poz. 34 ,Zbiór rozprawa o przedmiotach prawa polskiego (napisany przeze mnie) w Warszawie i Wilnie $1812 \ldots$ Dzieło to zawiera pod ogólnym tytułem trzy różne materie historyczno-prawne: 1 . Wywód praw miejskich w Polsce dawnej obowiązujących (s. 1-211). 2. Rzecz o uprawnieniu dzieci przez zaszły związek małżeński (s. 215-259) i 3. Wywód kary śmierci za kradzież postanowionej (s. 263-298)". Kiedy indziej odsyła do źródła zawierającego szczegółowy opis zawartości danego dzieła, np. przy poz. 384 ,Z dotrzymanego indigenatu Pruskiego dobro pospolite...” (1696) pisze: „Opis obszerny tego dzieła podaje Braun (s. 320, 323)". Bogactwo informacji zawartych w adnotacjach podnosi walory informacyjne i naukowe bibliografii oraz stanowi ważne źródło dla badaczy dziejów prawa i kultury polskiej.

Jeśli chodzi o układ, Bibliografia przedstawia się podobnie jak część prawnicza w Historii literatury polskiej Bentkowskiego. Układ ten uwzględnia zasady 
periodyzacji dziejów politycznych Polski, a więc podział na okresy historyczne, jest zatem układem chronologicznym. Ukazuje on występowanie polskiego piśmiennictwa prawniczego i autorów literatury prawniczej w poszczególnych okresach.

Cały materiał jest podzielony na cztery okresy:

\section{Okres pierwszy}

\section{Literatura praw polskich od czasów najdawniejszych} do rozwiazania bytu politycznego Polski

Oddział pierwszy

Źródła prawa polskiego

1. Dzieła dotyczące literatury praw polskich

2. Dzieła historyczne w prawach polskich

3. Zbiory praw polskich

A. Zbiór praw krajowych ogólnych czyli powszechnych
a) Same zbiory
b) Diariusze
c) Sumariusze i inwentarze

B. Zbiory praw krajowych szczególnych
a) Prawa prowincjalne
b) Prawo wydania swobody miejskiej
c) Prawo synodalne czyli soborów i zborów kościelnych
d) Prawo szczególne inne, mianowicie szkół, towarzystw uczonych, ordynacji, cechów itd.
e) Prawo obce, na które w prawodawstwie i prawnictwie polskim wzgląd miano
A. Prawo obce ogólne
B. Prawo obce szczególne

Oddział drugi

Pisarze prawni

1. Pisarze prawa publicznego polskiego

2. Autorzy prawa prywatnego polskiego

3. Autorzy praw kryminalnych krajowych i obcych

4. Autorzy praw obcych w Polsce obowiązujących
A. Autorzy prawa rzymskiego
B. Pisarze prawa kanonicznego
C. Pisarze prawa rzymskiego i kanonicznego obowiązującego
D. Autorzy prawa saskiego
E. Autorzy prawa chełmińskiego
F. Autorzy prawa lubeckiego
G. Autorzy prawa lennego

5. Pisarze postępowania sądowego wykładający 


\section{Okres drugi}

Dzieła prawnicze polskie wydane w prowincjach

zostajacych pod rzadem trzech mocarstw

1. Same zbiory
A. W prowincjach pod panowaniem rosyjskim
B. W prowincjach pod panowaniem pruskim
C. W prowincjach pod panowaniem austriackim

2. Dzieła prawnicze do tych praw należące
A. Co do Litwy, Wołynia
B. W prowincjach pruskich
C. W prowincjach austriackich

\section{Okres trzeci}

Prawodawstwo i prawnictwo Księstwa Warszawskiego

1. Same zbiory

2. Dzieła prawa publicznego Księstwa Warszawskiego tyczące się

3. Dzieła prawa prywatnego Księstwa Warszawskiego tyczące się

\section{Okres czwarty}

\section{Prawodawstwo i prawnictwo Królestwa Polskiego}

1. Królestwo Polskie

2. Pisarze o prawie w ogólności mówiący, a do szczególnego prawodawstwa stanowiącego nieprzywiązujące się prawa obce $\mathrm{w}$ języku polskim wydane

3. Pisarze na rozmaite prawa zapatrujące się

4. Pisarze prawa teraźniejszego Królestwa Polskiego rozbierający

Materiał dotyczący poszczególnych okresów ma układ systematyczny. Każdy dział i poddział poprzedzono objaśnieniami dotyczącymi jego zawartości. $\mathrm{W}$ poddziałach pozycje uszeregowano w porządku rzeczowym, tworząc grupy zagadnieniowe, a następnie chronologicznie, według dat wydania. Wyjątek stanowił poddział „Pisarze prawni”, w którym materiał zgrupowano według działów prawa, a następnie chronologicznie według haseł autorskich.

Po zrębie głównym dzieła zamieszczona została część pt. „Przypisy do załączenia pod kolumnami gdzie wypada", którą zredagował K. Bandtkie. Ma ona własną paginację - liczy 40 stron i zawiera 602 przypisy. Są tu odwołania do dzieł m.in. S. Hoppiusa, D. Brauna, J.D. Janockiego, F. Bentkowskiego, T. Czackiego, Jana Łaskiego, Józefa Maksymiliana Ossolińskiego, Jerzego Samuela Bandtkiego, a także do artykułów z czasopism, np. „Pamiętnika Warszawskiego” i „Dziennika Wileńskiego". Przypisy są na ogół skrótowe, operują często tylko nazwiskiem 
autora albo skróconym tytułem dzieła, rzadko jednym i drugim łącznie, oraz oznaczeniem tomu i strony. W wypadku ponownego, bezpośredniego odwołania się do danej pracy w kolejnym przypisie stosowano skrót „Tamże”. K. Bandtkie zerwał z umieszczaniem przypisów bezpośrednio po opisie bibliograficznym, jak ma to miejsce w rozdziale prawniczym Historii literatury polskiej Bentkowskiego i autografie. Przypisy, graficznie oznaczone małymi cyframi arabskimi, miały zostać wydrukowane u dołu stronicy.

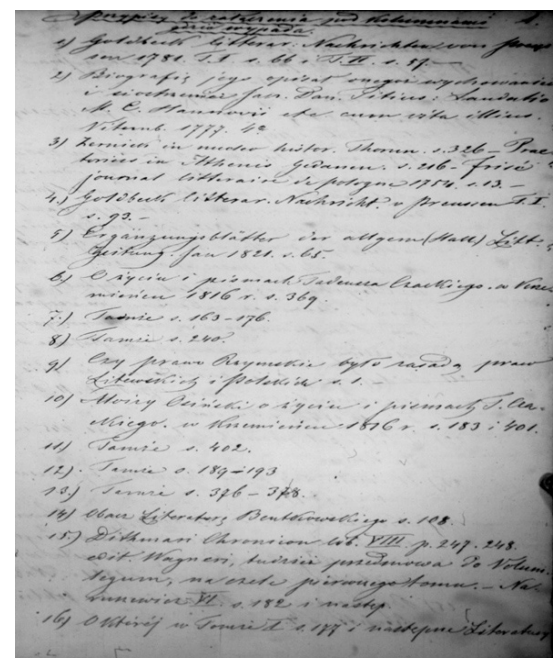

Rys. 7. Strona z części „Przypisy” z rękopisu

Bibliografia prawa polskiego od najdawniejszych czasów do roku 1823

napisana przez Jana Wincentego Bandtkie-Stężńskiego

Źródło: zbiory Biblioteki Jagiellońskiej, sygn. 4917;

Biblioteka Narodowa, mikrofilm sygn. 51252.

Na końcu dzieła planowano zamieścić „Spis rzeczy szczegółowych porządkiem alfabetycznym". Nie było to nic innego jak indeks alfabetyczny, na co wskazuje notka dla zecera: „Dokonać to w czasie druku zamieszczając ścisło alfabetycznie wszystkie nazwiska autorów i początek tytułu każdego dzieła, gdzie nie ma wyrażonego autora".

Dokładna analiza rękopisu Bibliografii wykazała, że ma on pewne mankamenty. Tekst jest skażony usterkami, nieścisłościami w zapisach bibliograficznych, które powstały zapewne podczas jego kopiowania. Są to omyłki w datach wydania, przekręcone wyrazy (np. „publika” zamiast „politica”). Do najpoważniejszych błędów należą zaburzenia w numeracji odnośników cyfrowych, odsyłających do części „Przypisy”. Bibliografia zamieszcza pozycje ponumerowane od 1 do 899, z tym, że powtórzone zostały numery 403, 404, 405, 406, 407, 408, 409, 410, 411, 
412, co daje 909 pozycji, a nie 899, jak jest w bibliografii. Podobny zamęt w numeracji panuje w „Przypisach”. Ponadto po końcowym przypisie 602 widnieją dodatkowe przypisy, mające odrębną numerację od 1 do 16. Są one trudne do zidentyfikowania z uwagi na niedokładne i skrótowe zapisy. Dlaczego K. Bandtkie nie przenumerował odnośników cyfrowych, mimo że na pewno zdawał sobie sprawę, iż te nieprawidłowości wyjdą na jaw podczas składania dzieła do druku? Trudno powiedzieć. Być może obawiał się przeprowadzenia szczegółowej bibliograficznej konfrontacji odnośników z przypisami, bo wymagała ona szerokiej wiedzy $\mathrm{z}$ zakresu historii prawa oraz dobrej orientacji w polskiej literaturze prawniczej i bibliograficznej. A on nie miał przecież żadnego przygotowania prawniczego, nigdy też nie zajmował się bibliografią, był w tych sprawach dyletantem. Wymownie potwierdza to choćby fakt, że nie podjął on próby rozwiązania skrótowych zapisów bibliograficznych w „Przypisach”, które dla użytkownika Bibliografii mogły być niezrozumiałe i niejasne.

Wydaje się, że intencją K. Bandtkiego było zachowanie struktury, metody opisu i układu dzieła w stopniu maksymalnym, a więc w postaci nadanej przez jego ojca. Dowodzi tego np. fakt, że w rękopisie utrzymano przyjętą czterdzieści lat wcześniej formę zapisu bibliograficznego, nieodpowiadającą panującym już wówczas zwyczajom. Dla użytkownika mogła ona wyglądać archaicznie, dziwnie, a nawet utrudniać poszukiwanie informacji. K. Bandtkie zamierzał też zachować przestarzały układ typograficzny druku, który nie spełniał już wymagań stawianych pracom bibliograficznym w drugiej połowie XIX w.

Po śmierci K. Bandtkiego w 1876 r. jego spadkobiercy, chcąc zapewne wypełnić ostatnią wolę zmarłego, postanowili znaleźć nakładcę na druk bibliografii. Ponieważ nie było mowy o tym, żeby zrobić to w Warszawie, postanowili przekazać rękopis Akademii Umiejętności w Krakowie, z nadzieją, że instytucja ta doprowadzi wreszcie do jego wydania. Akademia weszła w posiadanie rękopisu kilka miesięcy po śmierci K. Bandtkiego, prawdopodobnie pod koniec 1876 r. Sprawa Bibliografii była bowiem rozpatrywana już 10 stycznia 1877 r. na posiedzeniu Wydziału Historyczno-Filozoficznego. Postanowiono na nim odstąpić rękopis Komisji Bibliograficznej AU ${ }^{39}$. Miesiąc później (9 lutego), po przedstawieniu tej kwestii przez Józefa Szujskiego na posiedzeniu, wniosek ten poparł Wydział Filologiczny ${ }^{40}$. Zapewne Komisja Bibliograficzna miała za zadanie zaopiniować poziom opracowania dzieła pod względem wymagań naukowych i metodycznych stawianym pracom bibliograficznym i ostatecznie zdecydować o jego dalszym

${ }^{39}$ Posiedzenie Wydziału Historyczno-Filologicznego dnia 10 stycznia roku 1877, „Rozprawy i Sprawozdania z Posiedzeń Wydziału Filologicznego AU” 1877, nr 7, s. II.

${ }^{40}$ Posiedzenie wydziałowe dnia 9 lutego roku 1877, „Rozprawy i Sprawozdania z Posiedzeń Wydziału Filologicznego AU" 1878, nr 6, s. IX. 
losie ${ }^{41}$. Stanowisko Komisji musiało być negatywne, skoro do druku bibliografii nie doszło. Przypuszczalnie po zapoznaniu się z rękopisem uznano, że wymaga on solidnego dopracowania i rzetelnej „obróbki” metodycznej. Wobec tego, że Komisja miała w tym czasie partykularne interesy - była zaangażowana w publikację kolejnych tomów Bibliografii polskiej K. Estreichera, sprawa dzieła Bandtkiego zeszła na dalszy plan. Następnie rękopis został przekazany Bibliotece Jagiellońskiej.

W podsumowaniu należy stwierdzić, że Bibliografia J.W. Bandtkiego jest aktualna do dziś jako źródło informacji o polskiej literaturze prawniczej wydanej do $1823 \mathrm{r}$. Biorąc pod uwagę stan ówczesnej metodyki bibliograficznej, dzieło to pod względem koncepcji i metody opracowania stoi na wysokim poziomie. Nowatorski sposób ujęcia zakresu rzeczowego, dążenie do kompletności materiału, poszerzenie zasięgu wydawniczo-formalnego o artykuły z czasopism i rękopisy, rozbudowany aparat naukowy w postaci przypisów - wszystko to sprawia, że użytkownik tej bibliografii może w niej z powodzeniem szukać materiałów z zakresu prawa polskiego do początku XIX w. Dowodzi ona dużej świadomości bibliograficznej Bandtkiego, wynikającej z indywidualnej lektury i wielkiej znajomości polskiego piśmiennictwa prawniczego oraz związanej z nią umiejętności wartościowania go i poprawnego informowania o nim. O wartości naukowej Bibliografii świadczy uwzględnianie cytatów bibliograficznych, stosowanie adnotacji o treści czy cechach wydawniczo-formalnych opisywanych pozycji oraz rozszyfrowywanie niektórych pseudonimów, kryptonimów i anonimów. Naturalnie dziełu można by wiele zarzucić z perspektywy dzisiejszego stanu metodyki bibliograficznej. Trzeba jednak pamiętać, że metodyka ta w pierwszej połowie XIX w. dopiero zaczynała się rozwijać i że głównym celem twórczości bibliograficznej była rejestracja, utrwalenie dorobku piśmienniczego z danej dziedziny. Pod względem ogólnej metody bibliografię Bandtkiego cechował postępowy charakter w porównaniu do ówczesnych spisów bibliograficznych. Jest ona pierwszą nowocześnie opracowaną bibliografią prawniczą, a zarazem bibliografią dziedzinową, do dziś zachowującą walory naukowe $\mathrm{i}$ informacyjne.

Można sądzić, że gdyby Bibliografia Bandtkiego w odpowiednim czasie ukazała się drukiem, stanowiłaby do dziś stałą pozycję w polskim dorobku bibliograficznym w dziedzinie prawa. Wydaje się, że propozycję jej wydania uznano jednak za spóźnioną. Dzieło nie spełniało bowiem wymagań metodycznych i metodologicznych stawianych pracom bibliograficznym w drugiej połowie XIX w. Szkoda, że wysiłek J.W. Bandtkiego włożony w jego przygotowanie nie został doceniony. Na losie bibliografii zaciążyła niewątpliwie postawa K. Bandtkiego, który bezkompromisowo dążył do druku dzieła, nie bacząc na to, że wymaga ono

${ }^{41}$ W tym czasie przewodniczącym Komisji Bibliograficznej Akademii Umiejętności był wybitny bibliograf Karol Estreicher, twórca retrospektywnej Bibliografii polskiej; funkcję tę pełnił on w latach 1873-1888. 
należytego dopracowania pod względem merytorycznym i edytorskim. Niestety, błąd ten popełnił dwukrotnie.

Zaprezentowana tu rękopiśmienna Bibliografia prawa polskiego J.W. Bandtkie-Stężyńskiego pozwala także na sformułowanie pewnych uwag i sugestii. Dzieło to ma duże znaczenie dla badań nad historią prawa polskiego. Do 1800 r. właściwie nie może być zastąpione żadną inną bibliografią. Tylko w niewielkim stopniu pokrywa się zasięgiem chronologicznym (23 lata) z bibliografią prawniczą A. Suligowskiego, obejmującą okres 1800-1910, przez to nie traci na wartości informacyjnej dla historyka prawa zajmującego się czasami staropolskimi. W porównaniu do Bibliografii historii polskiej Ludwika Finkla, rejestrującej również literaturę prawniczą do 1815 r., za dziełem Bandtkiego przemawiają liczne adnotacje księgoznawcze i treściowe oraz to, że nie wymaga - jak to ma miejsce w pracy Finkla - przeglądania dodatkowych działów, oprócz wyodrębnionego działu „Prawo”, aby uzyskać komplet informacji z tej dziedziny. Jeszcze trudniejsze jest wyszukanie literatury prawniczej w Bibliografii polskiej Karola Estreichera, rozproszonej na skutek zastosowania układu alfabetycznego. Z tych to powodów Bibliografia Bandtkiego wykorzystywana jest do dzisiaj przez badaczy ${ }^{42}$. Warto byłoby więc pomyśleć nad jej ewentualnym udostępnieniem w formie drukowanej lub cyfrowej (np. w PDF), po odpowiednim opracowaniu redakcyjno-edytorskim i metodycznym. Niewątpliwie stanowiłaby ona jedną z podstawowych pomocy informacyjnych $w$ badaniach historii prawa polskiego do początków XIX w.

\author{
HANDWRITTEN BIBLIOGRAFIA PRAWA POLSKIEGO \\ OD NAJDAWNIEJSZYCH CZASÓW DO ROKU 1823 [A BIBLIOGRAPHY \\ OF POLISH LAW FROM THE EARLIEST TIMES UP TO 1823] \\ BY JAN WINCENTY BANDTKIE-STĘŻYŃSKI \\ IN THE COLLECTIONS OF THE JAGIELLONIAN LIBRARY
}

\begin{abstract}
Lawyers in the Kingdom of Poland drew attention to the lack of lists of professional literature already at the beginning of the $19^{\text {th }}$ century. Legal literature was so vast that it became a necessity to systematize and compile it in bibliographies. Jan Wincenty BandtkieStężyński (1783-1846), an authority on the history of Polish law, was one of the first scientists to undertake this task. In 1824, he finished working on a retrospective bibliography of Polish law up to 1823. However, his work was not published during his lifetime. After Bandtkie's death, Kazimierz Bandtkie-Stężyński, his son, made another attempt to publish the bibliography which turned out to be unsuccessful as well. Although Bibliografia prawa polskiego od najdawniejszych czasów do roku 1823 [A Bibliography of Polish Law from the

${ }^{42}$ Wspomina o tym W. Sobociński, Jan Wincenty Bandtkie obrońca Kodeksu Napoleońskiego, „Rocznik Lubelski” 1960, nr 3, s. 161.
\end{abstract}


Earliest Times up to 1823] exists only in the form of a manuscript, it is recognized as the first Polish bibliography concerning law. Bandtkie's bibliography was novel mostly due to its scope. It covered only legal literature whereas it was registered as a general bibliography at the time. Even though there were some methodological errors, Bandtkie's bibliography has stood the test of time and it serves as a useful and valid source of information to this day.

Keyw ords: Jan Wincenty Bandtkie-Stężyński, law bibliography, law, XIX century 